\title{
DETERMINANT OF THE DEVELOPMENT OF THE PRECIOUS METALS MARKET AND PECULIARITIES OF INVESTMENTS IN PRECIOUS METALS
}

\author{
Oleksandr Ksenzhuk \\ Department of International Economics \\ Ternopil National Economic University \\ 11 Lvivska str., Ternopil, Ukraine, 46020 \\ Rockgorn@gmail.com
}

\begin{abstract}
It is argued that precious metals function as an attractive investment means for hedging in the period of appearing high liquidity risks of other financial assets. There was revealed the rationality of using precious metals not only for protecting from high risks and also for profit making. It was established, that favoring the development of the market of precious metals improves the financial-investment climate of a country. Precious metals function as a valuable asset that improves the credit trust level and prevent crises of efficiency, liquidity and default. There is grounded the influence of globalization on functioning of the world market of precious metals and their investment attractiveness. Factors that influence the development of the precious metals market are determined. The role of price formation in functioning and stability of the precious metals market is determined. There was argued, that the mechanism of price formation - is a multi-factor process; precious metals are indicators of the general state of world economy: gold draws the greatest attention of investment-seeking economic agents; platinum price indicates the state of economic and financial processes to the date; silver and palladium are found to be not elastic and highly dependent of demand created by industrial economic entities; gold is regarded as the financial asset of the highest liquidity level in the structure of gold and currency reserves across countries worldwide, ten countries keep leading positions, most of them demonstrate stable indices. The analysis of the dynamics of prices and modern tendencies at the world precious metals market allows to reveal their functional destinations as a means for determining a cost limit of a good, investment instrument, provident fund of the money system of a state, means of accumulation and creation of treasures, we can conventionally separate direct and intermediate factors that have the most influence on price formation of one or another precious metal.
\end{abstract}

Keywords: precious metals, gold, investment, conjuncture, minimization of risks, market of precious metals, hedging.

\section{Introduction}

Precious metals (gold, silver, platinum, palladium) is a type of financial assets that has enough causes to be one of most popular investment instruments. The development of this segment of the financial market directly influences financial-investment possibilities of a country that can be realized through both own financial institutions and correspondent structures with the foreign capital. Precious metals are an important reserve asset that increases also political, external economic and social advantages of one or another country at the international arena. The investment function of precious metals is conditioned by the fact that, in first, reserves volumes of precious metals, especially, gold, of a country testify to its currency-financial stability, credit and competitive abilities at the world market. At second, processes, connected with mining, using, circulation, consumption and storing precious metals take place with involving a great number of participants, each of them has own interest, especially such as state structures and controlling bodies, commercial banks, financial-investment structures, industrial enterprises, private companies, physical persons and other. At the same time precious metals as a main liquid and investment resource of a country are characterized with functional binarity, because they can be used as both raw materials for production and as an investment instrument.

Taking into account the modern state of world economy, precious metals attract investors' interest as an object of long-term investment with the high efficiency and reliability comparing with other financial assets.

Modern scientific studies deal with the development of both separate market segments and processes, connected with their circulation, accumulation, investment and so on. Analyzing structural and institutional aspects of functioning of the precious metals market, researchers are 
unanimous that the bank infrastructure as to operations with these types of assets is essentially activated today, and prognosticate the widening of their forms, development cannels and functions under conditions of the further intense use $[1,2]$. Studies demonstrate the weak casual connection between investments in precious materials and high profitability level that testify that the function of hedging and diversification of investment portfolio is most typical for precious metals [3, 4]. But scientific literature doesn't contain enough information as to a possibility of using precious metals immediately as instruments for profit-making.

\section{Aim of research}

The aim of this research is revelation of determinants of the development of the precious metals market and peculiarities of investment in precious metals.

\section{Materials and methods}

A methodological base of the study is the dialectic method of scientific cognition and fundamental theses of the theory of international economy. Base scientific research results are obtained based on using common scientific and special research methods: methods of analysis, generalization and synthesis - for revealing tendencies of the development of the world precious metals market, factors of influence of formation of world prices for precious metals and structures of the world precious metals market in the context of the reserve fund of precious metals of world countries with most reserves; graphic method - for visualizing stages and results of the research process; abstract-logic method - for forming research conclusions.

\section{Results}

The world financial market and its main segments under the influence of globalization processes that provoke financial instability in the last decade, suffers from certain difficulties in the development and is sensitive to external challenges, so, already existent financial and institutional risks increase. International organizations prognosticate the further economic growth in the world (just now the economic growth is observed, but its rates are essentially lower than in the pre-crisis period [5]), and indicate the weakness of this stability, because any shifts can cause changes at world markets and spread at most countries that need introducing preventive arrangements [6]. Despite other functions (use as a raw material for jewellery business, in different technological processes, as a reserve means and so on), precious metals under these conditions become an object of the increased interest among individual and institutional investors in the context of diversification of the investment portfolio for minimizing risks, connected with modern tendencies of world economy. The aforesaid just conditions the specificity of the development and functioning of the precious metals market, depending on a series of factors, manifested at all circulation stages - from exploration and mining to consumption. Among main ones we can separate: institutional business, readiness of national markets to work with precious metals, adaptability of national regulatory mechanisms to world tendencies of financial liberalization and openness, activity of investors, volume of gold and currency reserves, currency fluctuations (first of all, American dollar), use of trade and investment protectionist arrangements by countries and so on. At the same time the precious metals market is characterized by the high maneuverability to the changing external environment, because the endured long-term historical process of formation (for example, in certain periods gold and silver functioned as money, but after demonetization of gold their main role moved to the sphere of commodity relations).

Under modern conditions gold remains an important source of investment [7], although the precious metals market, especially gold one, is characterized by prices volatility, jewellery and industrial demand for gold continues to fall, activity of central banks decreases, cost price of mining of an ounce of gold decreases too [8]. The volume of the world export of gold in 2016 was 324.6 bil USD, main exporters are Asian countries (share of gold export in the dollar equivalent is 120.8 bil USD) $37.2 \%$ of the world export. Export from European countries is $35.5 \%$ (25.3\% of the world export is at Switzerland), export of countries of the Northern America is $10.8 \%$, Latin America and Caribbean basin $-6.5 \%$, Africa and Oceania - $4.9 \%$ [9]. In 2017 the world precious metals market faced 
negative tendencies. Thus, the world volume of gold mining deceased to 3247 tons, the secondary processing of gold decreased by $7.4 \%$ comparing with 2016 (Table 1).

Table 1

Volumes of gold export by 15 most world exporters in 2016.

\begin{tabular}{ccc}
\hline Country & Export volume in bill USD & Share of gold export in the world volume of it \\
\hline Switzerland & 82.3 & $25.30 \%$ \\
Hong Kong & 54.1 & $16.70 \%$ \\
UAE & 25.4 & $7.80 \%$ \\
USA & 17.7 & $5.40 \%$ \\
Great Britain & 15.7 & $4.80 \%$ \\
Australia & 13.5 & $4.10 \%$ \\
Canada & 12.5 & $3.80 \%$ \\
Turkey & 8.2 & $2.50 \%$ \\
Japan & 7.3 & $2.30 \%$ \\
Thailand & 7.3 & $2.20 \%$ \\
Peru & 6.4 & $2 \%$ \\
Germany & 5.2 & $1.60 \%$ \\
Mexico & 4.9 & $1.50 \%$ \\
India & 4.3 & $1.30 \%$ \\
Ghana & 3.7 & $1.20 \%$
\end{tabular}

Note: constructed by the author, based on data [9]

Analyzing the conjuncture of the world precious metals market, one must pay attention to different scientific approaches to determining their role in economy and society of any country. Thus, several scientists are inclined to adaptive properties of precious metals regarding market needs. That is, gold, silver and so on can at the same time function as accumulation and circulation, influencing the balance of world prices. So, the dependency between currencies and precious metals as a means of fighting against inflation is extremely important. From the other side, instability of prices for precious metals often results in economic crises, so they (precious metals) must not be used as an absolute criterion for other goods [1].

Considering the dynamics of world prices for precious metals for 2010-2017, the period after the global financial crisis, it must be noted that there was observed a tendency to decreasing the cost of all precious metals to 2015. Such tendency is conditioned by political changes in the USA and deflation threats in most world economies. The essential difference in tendentious percent ratio between gold/silver and platinum/palladium can be explained by the essentially higher demand for the first group of precious metals in industry and investment activity comparing with platinum and palladium, essential rise of palladium in price. The growth of price for palladium is conditioned by the growth of speculative demand as a result of increased industrial needs and prognoses of the short-term deficit of this metal at the world market. It is worth noting that a price for palladium reaches its maximal value for the last two decades. The last price record was overcome by this precious metal in 2001 (Fig. 1), when it cost 914.7 doll per ounce [10]. At the same time the unessential rise of gold price, fall of silver and platinum price are connected with shortening the number of purchases of these precious metals by exchange funds.

The total dynamics of world prices for precious metals for 2005-2017 is presented on Fig. 1. As we can see, gold is most stable, and obviously is not inclined to lose positions, and its 
fall usually has a temporal character that one more time proves a researchers' conclusion about the great value of this metal in international social economic relations. Rest of precious metals are remarkable for abrupt fluctuations of prices, and only a price for silver doesn't change in the limited diapason, without demonstrating essential deviations.

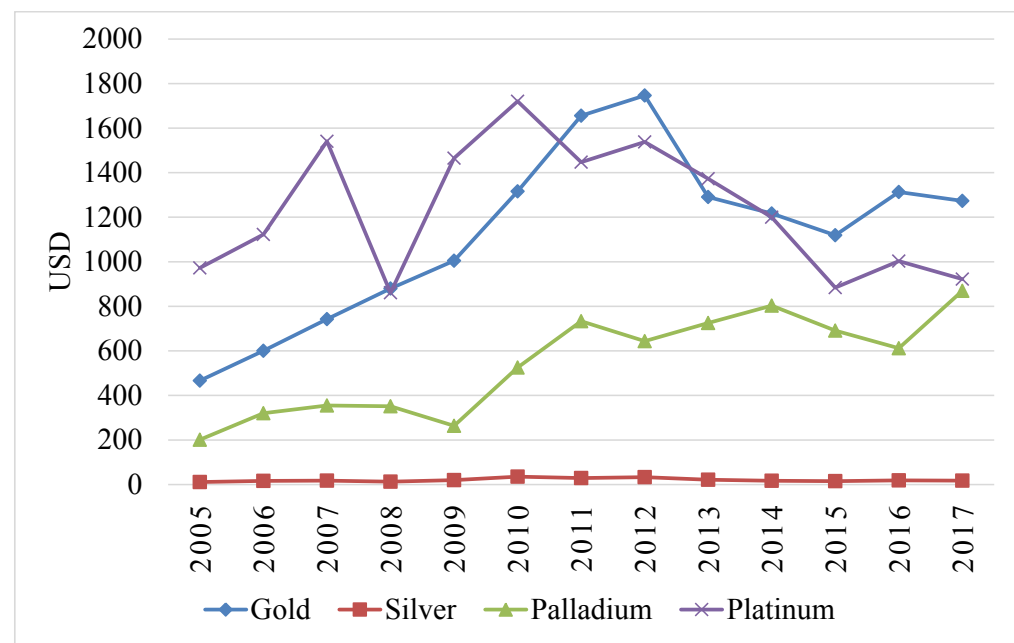

Fig. 1. Dynamics of world prices for precious metals in 2005-2017: constructed by the author based on data $[1,10-12]$

In 2017 there was observed a tendency to the insufficient growth of prices for gold and palladium. As opposite, silver and platinum a bit lost their positions. Tracing a parallel with the previous period in 2016 a gold cost grew inessentially - only by $0.7 \%$, silver and platinum became cheaper by $11 \%$ and $8.8 \%$ respectively, and palladium grew in price by $54 \%$.

The analysis of the dynamics of prices and modern tendencies at the world precious metals market allow to reveal their functional destination as a means for determining a cost limit of a good, investment instrument, provident fund of the money system of a state, means of accumulation and creation of treasures, we can conventionally separate direct and intermediate factors that have the most influence on price formation of one or another precious metal. Price formation at world precious metals markets depend on direct and intermediate factors that realize the most influence on price formation of one or another precious metal [13].

Direct influence factors include, in first, the industrial demand as one of catalysts of changing a price of one or another precious metal. Most consumers of precious metals are usually jewellery industry, electric technical industry, chemical machine building, production of medical laboratory technique, photo- and cinema industry and other [14]. At second, the economic-political state of leading world countries, especially USA. For example, in the pre-crisis period of 2008 there was observed a tendency of shortening world gold reserves, at the same time after ending the crisis, gold reserves abruptly grew, having returned them leadership as a most reliable source of investment at world financial markets. At third, geopolitical, financial-economic and social globalization processes essentially correlate the growth of prices for precious metals in different countries depending on their income levels and volumes of gold reserves. At fourth, the interest of private investors must be taken into account, because just investments cause may be most important changes in the price policy of precious metals.

Among intermediate (indirect) influence factors are, in first, a price for petroleum that however plays a rather important role, influencing price fluctuations as to precious metals statistically. Thus, according to studies, a price for gold grows in average by $1.6 \mathrm{USD}$, silver - by 0.06 USD in direct proportion with rising a price for petroleum [15]. In second, fluctuation of an exchange rate of USD; in third, fund indices of world financial markets, at fourth, mutual influence of prices for other precious metals, that is we talk about the interconnection between precious metals of adjacent markets [16]. 
Despite the multi-factor type and complication of a precious metals price formation mechanism, they are most attractive for investment comparing with other financial assets [17]. For example, gold is characterized, in first, by unique qualities able to satisfy needs of investment funds; in second, by the long-term development trajectory without any, even short-term, risks; in third, the highest liquidity among all other financial assets of the world; in fourth, only partial dependence on a price for petroleum; at fifth, evolution that only strengthen wealth of nations with time [2]. Liquidity of precious metals in general gives a possibility to realize them at the market fast and without essential losses, transforming metal costs in cash [18]. Gold remains the most important share of reserves of any state and international structures [19]. For a long time 10 countries with most gold reserve are stable in the structure of total gold reserves of the world, that is totally $70 \%$ of volumes of gold reserves of all other world countries (Fig. 2).

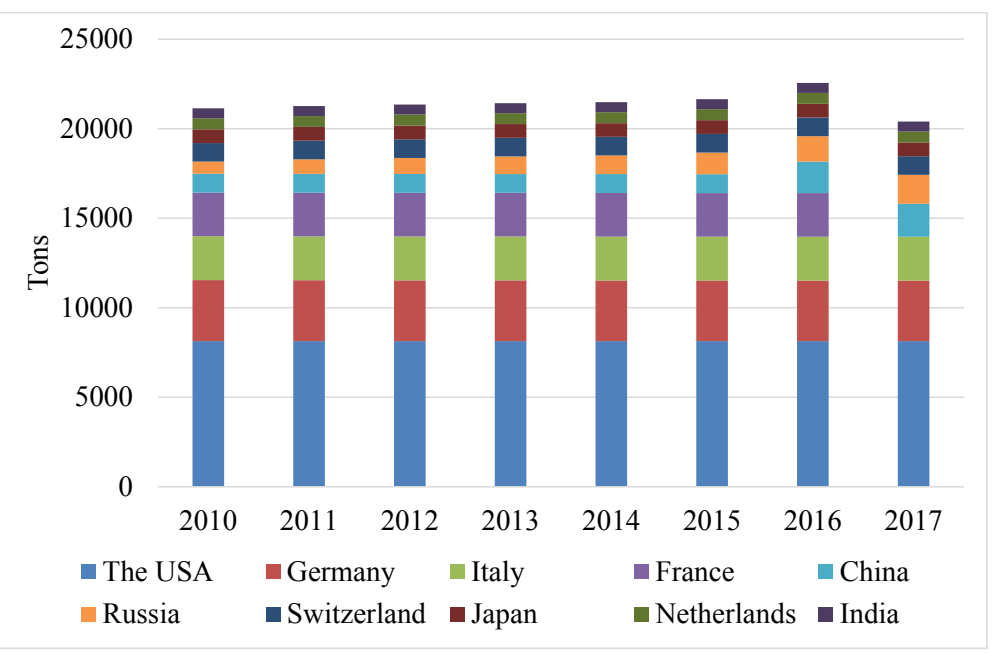

Fig. 2. Dynamics of joint gold and currency reserves of the world countries with most gold reserves for 2010-2017: made by the author according to data $[4,11,20]$

The dynamics demonstrates that most stable volumes of gold reserves during the aforesaid time are inherent to USA, Italy, France, Switzerland, Japan, Netherlands, India. The essential increment of gold is observed in China (by $74.8 \%$ in 2017 comparing with 2010) and Russia (almost by $139 \%$ for the last seven years). As opposite, gold reserve volumes in Germany a bit shortened (by $0.9 \%$ in 2017 comparing with 2010). The priority of gold in gold and currency reserves in world countries is explained by the continuously ascending trend for the world gold price (Fig. 3).

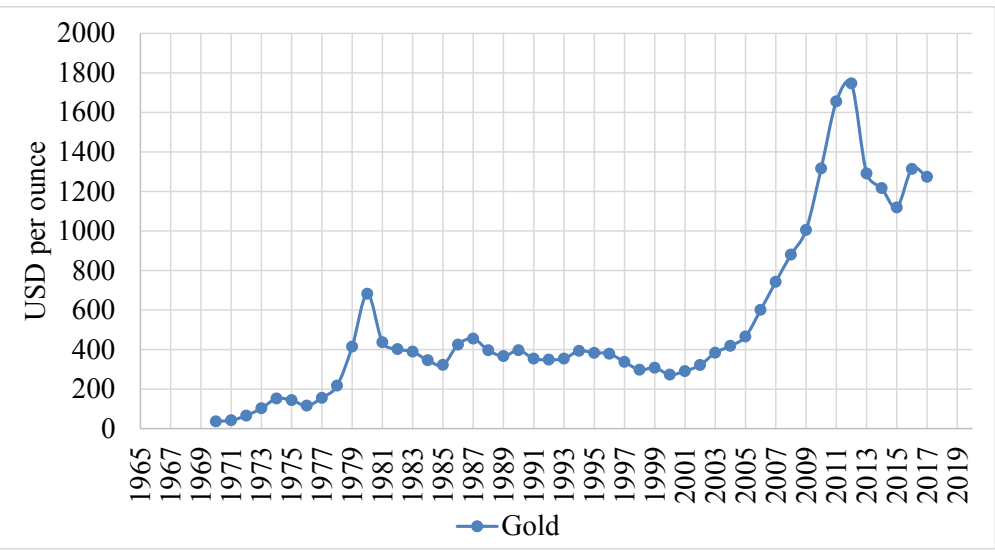

Fig. 3. Dynamics of gold prices in 1970-2017: made by the author based on data [3, 4] 
Fig. 3 presents the dynamics of gold prices for 1960-2017 that demonstrates the ascending trend. The essential growth of gold prices took place in 1980 and 2010 as a result of the influence of unfavorable political and economic factors. In these periods the attractiveness of gold as an investment instrument is conditioned by a necessity of hedging.

\section{Discussion}

Regarding the growth of global changes, instability of the internal environment of countries for stabilizing both national and world precious metals and stones markets, it is necessary to introduce arrangements for increasing the effectiveness of functioning of the precious metals market for improving the investment climate: introduction of new technical and technological capacities; elaboration of state regulatory strategies and creation (reorganization) of institutions, empowered to control the circulation of precious metals and stones; intensification of the state testing control of production, non-targeted use, storage of precious metals and stones; formation of the transparent market and prevention of using shade schemes.

Precious metals are important components of investment portfolios for individual and institutional investments due to their physical-chemical properties that allow to play the role of a reliable hedging instrument in a long-term perspective. Regarding their effectiveness as investment instruments, it is recommended to invest in precious metals not only for hedging, but also in periods of high risks for profit making. The profitability of precious metals depends on economic and political situations.

\section{Conclusions}

1. Under modern conditions of globalization, transformation processes, especially in the financial sector, the development of the world precious metals market is raising. Because the long financial experience demonstrated the reliability of gold and other precious metals as an important financial asset for diversifying the investment portfolio, hedging and profit making.

2. In the crisis period including 2015 there was observed a tendency to decreasing a price of all precious metals. In 2017 prices for gold and palladium inessentially grew. At the same time silver and palladium continued to fall. The analysis of the dynamics of prices and modern tendencies at the world precious metals market allows to reveal their functional destinations as a means for determining a cost limit of a good, investment instrument, provident fund of the money system of a state, means of accumulation and creation of treasures, we can conventionally separate direct and intermediate factors that have the most influence on price formation of one or another precious metal.

3. The study of influence factors on the policy of forming prices for precious metals at the world market allowed to separate them conventionally in direct and indirect (intermediate). It was established that the most influence on costs of precious metals in general is realized by such factors as industrial demand, economic-political and social state of leading World countries, geopolitical, financial-economic and social globalization, interest of private investors (direct factors); petroleum price, USD exchange rate, fund indexes of world financial markets, cost for precious metals at adjacent financial markets (indirect factors).

4. Precious metals are some kind of indicators of the general state of world economy. In this context the special importance is inherent to the ratio between gold and platinum costs. And although gold is much more popular among investors, demonstrating investment moods, just platinum prices reflect real financial-economic processes. Prices for silver and palladium are not elastic and usually depend on needs of different industrial branches.

As a result of grounding investment advantages of precious metals, especially gold as a most liquid financial asset, we succeeded in finding out that this financial instrument is characterized by the long-term effectiveness with minimal investment risks and is a guarantee of wealth of each nation.

\section{References}

[1] World Economic Outlook. Seeking Sustainable Growth: Short-Term Recovery, Long-Term Challenges (2017). Available at: https://www.imf.org/en/Publications/WEO/Issues/2017/09/19/world-economicoutlook-october-2017 
[2] Global Financial Stability Report/ Global Financial Stability Report October 2017: Is Growth at Risk? (2017). Available at: http://www.imf.org/en/Publications/GFSR/Issues/2017/09/27/global-financial-stability-report-october-2017

[3] Ivanyshyna, H. S. (2017). Analiz svitovoho rynku dorohotsinnykh metaliv. Ekonomichnyi visnyk universytetu, 35/1, 205-213.

[4] GFMS GOLD SURVEY 2017. Available at: https://plataformaenergetica.org/sites/default/files/ Thomson_Reuters_GFMS_GOLD_SURVEY_\%202017.pdf

[5] Workman, D. (2018). Gold Exports by Country. World's Top Exports. Available at: http://www. worldstopexports.com/gold-exports-country/

[6] Doskochynska, L. S. (2017). Svitovi rynky dorohotsinnykh metaliv v umovakh finansovoi hlobalizatsii. Lviv, 22.

[7] Historical palladium (2018). London Fix. Available at: http://www.kitco.com/charts/historicalgold.html Last accessed: 28.07.2018

[8] Gold price (2018). World Gold Council. Available at: https://www.gold.org/data/gold-price Last accessed: 28.07 .2018

[9] Silver prices - 100 year historical chart (2018). Macrotrends. Available at: https://www.macrotrends.net/1470/historical-silver-prices-100-year-chart Last accessed: 28.07.2018

[10] Platinum prices (2018). Apmex. Available at: https://www.apmex.com/spotprices/platinum-price Last accessed: 28.07.2018

[11] Hood, M., Malik, F. (2013). Is gold the best hedge and a safe haven under changing stock market volatility? Review of Financial Economics, 22 (2), 47-52. doi: http://doi.org/10.1016/j.rfe.2013.03.001

[12] Riley, C. (2010). A new gold rush: Investing in Precious Metals. The Journal of Investing, 19 (2), 95-100. doi: http://doi.org/10.3905/joi.2010.19.2.095

[13] Poliakova, Yu. V. (2016). Svitovi rynky dorohotsinnykh metaliv v umovakh hlobalnoi ekonomiky. Ekonomichni nauky, 9. Available at: http://journals.iir.kiev.ua/index.php/ec_n/article/view/3059

[14] Shafiee, S., Topal, E. (2010). An overview of global gold market and gold price forecasting. Resources Policy, 35 (3), 178-189. doi: http://doi.org/10.1016/j.resourpol.2010.05.004

[15] Official gold reserves (2018). World Gold Council. Available at: https://www.gold.org/data/ gold-reserves Last accessed: 28.07.2018

[16] Gold reserves by country as of november 2017 (in metric tons) (2018). Statista. Available at: https:// www.statista.com/statistics/267998/countries-with-the-largest-gold-reserves/ Last accessed: 28.07.2018

[17] India gold reserves (2018). Trading Economics. Available at: https://tradingeconomics.com/india/gold-reserves Last accessed: 28.07.2018

[18] Hillier, D., Draper, P., Faff, R. (2006). Do Precious Metals Shine? An Investment Perspective Financial Analysts Journal, 62 (2), 98-106. doi: http://doi.org/10.2469/faj.v62.n2.4085

[19] Kim, J. H., Shamsuddin, A. (2008). Are Asian stock markets efficient? Evidence from new multiple variance ratio tests. Journal of Empirical Finance, 15 (3), 518-532. doi: http://doi.org/10.1016/ j.jempfin.2007.07.001

[20] Areal, N., Oliveira, B., Sampaio, R. (2013). When times get tough, gold is golden. The European Journal of Finance, 21 (6), 507-526. doi: http://doi.org/10.1080/1351847x.2013.854821 